\author{
Agnieszka Modzelewska \\ University of Bialystok \\ Poland \\ agnieszkagodlewska2@gmail.com \\ ORCID ID: https://orcid.org/0000-0002-8332-4101
}

Paulina Grodzka

University of Bialystok

Poland

paula.grodzka1@gmail.com

ORCID ID: https://orcid.org/0000-0003-0031-5363

\title{
TAX FAIRNESS AND CRYPTOCURRENCY
}

\begin{abstract}
Reluctance to pay taxes is a natural feature of man. Given the above, it is not surprising that taxpayers are constantly looking for all possible ways to avoid taxation. The legislator, realizing the above, introduces a number of regulations aimed at counteracting dishonest actions of taxpayers. In the context of cryptocurrencies, these are in particular solutions aimed at limiting anonymity in the circulation of cryptocurrencies. The taxpayers, taking advantage of the fact that trading in cryptocurrencies is very specific, complicated and partially anonymous, try to outsmart the tax authorities and pay no taxes on income from such transactions. Also, the fact that until January 1,2019 , there was no regulation regarding the taxation of cryptocurrencies, and the introduced regulation also raises many doubts, does not encourage taxpayers to honestly settle accounts with tax authorities. Tax authorities, on the other hand, do not have the tools that would enable them to counteract taxpayers' dishonesty effectively, what leads to the depletion of tax liabilities.
\end{abstract}

Keywords: anonymity, cryptocurrency, virtual currency, tax evasion, tax fairness

\section{Introduction}

One of the most famous examples proving that taxes should be paid is the case of the American gangster Al Capone. The authorities were unable to prove him other offenses, thus accused and convicted him for avoiding paying taxes. This problem remains valid today, as taxpayers undertake all, not always lawful, actions aimed at reducing taxation or its complete avoidance. This is also an issue in the case of virtual currencies (cryptocurrencies), which due to their specificity, seem to taxpayers to be a good way to avoid the payment of tax on income derived from the paid disposal of virtual currencies. The main aim of this article is to analyse the taxation of cryptocurrencies in relation to tax fairness. The article uses formal-dogmatic analysis and literature analysis.

\section{Main part}

J. J. Rousseau rightly claimed that "man is born free, and everywhere is in a grip". Undoubtedly, the limitations of freedom in the form of imposed taxes fall within the scope of these grip about which the French philosopher wrote. The property is subject to constitutional protection because everyone has the right to it [Journal of Laws of 1997, no. 78, item 483]. This protection is equal for everyone, and the property itself may be limited only by law and only to the extent that its essence is not affected. On the other hand, according to Article 84 of the Constitution of the Republic of Poland, "everyone is obliged to bear public burdens and benefits, including taxes, specified in the Act" [Journal of Laws of 1997, no. 78, item 483]. It is not without a reason that tax law, apart from criminal law, 
is said to be the most detrimental to the freedom of the individual.

One of the natural instincts of man, settled in his vital sphere of the psyche, is a reluctance to pay taxes [Kosikowski 2007, pp. 138-164]. The English satirist Jonathan Swift, who lived in the $18^{\text {th }}$ century, claimed that "in tax matters, two times two is sometimes not four, only one". This is due to the fact that high tariffs encourage smuggling and high taxes encourage tax evasion. This rule, sometimes called the tax multiplication table, is still valid today because the increase in tax is not always accompanied by an increase in budget revenues [Gomułowicz, Mączyński 2016, p. 360]. According to A. Gomułowicz, "no tax system has ever been, is not and will not be based on trust in the taxpayer, and resistance to the implementation of tax obligations will always be related to reluctance to pay taxes" [Gomułowicz, Mączyński 2016, p. 375]. Even the definition of tax contained in the Tax Code indicates one of its most important features - coercion [Journal of Laws of 2018, item 800 , as amended]. This means that there is a relationship of subordination between the entity obliged to pay the tax and the entity that has the authority to impose it. Rousseau pointed out that the word "tax is a slave word", therefore, the necessity of its payment arouses resistance, and when it becomes nuisance, it even leads to tax fraud [Kosikowski 2007, p. 251]. This resistance occurs even when the taxpayer is aware of the need to pay taxes.

Taxpayers make their own analysis and decide whether and to what extent to avoid taxes by deliberately lowering tax liabilities. They do so, considering the risk of control, as well as the possibilities that arise from a possible escape from the payment of tax. There are different types of tax evasion, from the least harmful to the most serious. The least harmful way to avoid taxation is to use programmes and schemes according to their purpose, under the applicable law. Tax abuse is another way to escape taxation. It also involves the use of schemes based on legal provisions, however, this use is inconsistent with these provisions. Tax evasion is a criminal attempt to avoid payment of tax by concealing or altering the facts. The most serious way is tax fraud understood as criminal attempts using extensive structures to avoid payment of tax or illegal tax refund [Klonowska 2017, p. 17].

The phenomenon of tax avoidance is influenced by both economic and psychological conditions. These factors are interdependent because taxation meets the psychological limit, where it comes to the fact that due to the excessive tax burden, budget revenues are not realized in the intended amount [Gomułowicz 2001, p. 82]. The actions taken by the taxpayer to avoid tax, used in private life, are generally considered unfair. If, however, they apply to the state, they do not raise so many ethical objections. The failure to punish taxes imposes on punishment [The failure to pay taxes results in penalties,] but does not burden the conscience [Gomułowicz, Mączyński 2016, p. 361]. Undoubtedly, tax avoidance is also affected by the provisions regarding possible liability and the possibility of detecting perpetrators of such acts.

Already the Gospel of Matthew contains a very interesting passage about the need to pay taxes. Disciples asked Jesus if they should pay tax to the emperor or not. And he, watching the denarius containing the image and the imperial inscription, answered that they should render to the Caesar what is Caesar's, and to God, what is God's [The Bible, Matthew 12:12-17]. According to A. Gomułowicz, the described scene presents the tax order of conscientiousness passed on by Jesus to his disciples [2010, p. 99]. It also displays that paying taxes is not only a strictly fiscal issue but also an ethical and moral problem. Individual attitudes of taxpayers (tax morality) towards taxation are shaped in the evolutionary process taking place within the framework of specific social, economic and systemic conditions. In addition, they are conditioned by cultural tradition (tax mentality). Tax mentality means an attitude towards taxes represented by a social group that the taxpayer identifies with and belongs to [Schmölders 1932]. There is a model of variables shaping the attitudes of taxpayers towards taxation of income, which assumes that the behaviour of the taxpayer depends largely on the social group to which they belong. This is due to the fact that the awareness of perception of people committing the crime or fiscal offenses has a social character because some views or behaviours are disseminated within a given community [Sztopmka 2002, p. 295]. A taxpayer who has made a profit and loss analysis, considering social premises, can get approval in a group that recognizes tax evasion as a sign of cunning and resourcefulness [Leoński 2013, p. 159]. Thus, tax mentality is an area of social awareness that reflects the attitude towards civic duty, which is the payment of taxes [Pasternak-Malicka 2013 , p. 89]. Social awareness is one of the factors that are crucial in the process of creating the law. In addition, it is one of the main conditions for the effectiveness of the law [Borucka-Arctowa 1980, p. 153]. In turn, tax morality can be understood as an internal acceptance of 
a tax obligation or its absence, as well as an assessment of attitudes towards compliance with or evasion of tax obligations [Gomułowicz, Mączyński 2016, p. 370]. Morality, including tax morality, affects conscience, and thus goes deeper than the constituted law, which deals with the outside of the proceedings [Ziembiński 1980, p. 3]. This means, therefore, that if taxpayers are obliged to pay tax, they see a moral aspect in a correct manner and will pay tax liabilities.

As previously indicated, taxpayers are looking for loopholes that avoid tax payment. The dishonest ones also use the weaknesses of the state apparatus or new technological solutions. The emergence of the first cryptocurrency - Bitcoin in 2009 undoubtedly caused much confusion on the financial market. Cryptocurrencies should be understood as relations of nodes created in the peer to peer network, which is assigned to the users' portfolios [Kozłowska 2018, pp. 29-33]. By assumption, the functioning of cryptocurrencies, otherwise known as virtual, cryptographic or electronic currencies, was to be deprived of any administrative control, independent of central banks, and the course was to be shaped on the basis of market mechanisms. Cryptography was to be used to control emissions and trade in virtual currencies. The process of creating the value of the portfolios of users of most cryptocurrencies is based on an encrypted electronic accounting system while storing data about the status of virtual coins held. Although virtual currencies are not generally accepted as payment means, they are treated as money by many network users. This is due to the fact that they fulfil the payment function as a rule. They are also a medium of exchange and a measure of value. In addition, they fulfil the function of value retention and risk transfer to a greater extent than money [Dąbrowska 2017, p. 55]. What is more, cryptocurrencies can be traded and invested by multiplying assets method. Exchange of cryptocurrencies takes place mainly through the use of cryptocurrencies. These exchanges are digital platforms that allow, by publishing users' offers, exchange of virtual currencies into fiat money or other virtual currencies.

Both the Act on Corporate Income Tax [Journal of Laws of 2018, item 1036, as amended] and the Act on Personal Income Tax [Journal of Laws of 2018, item 1509, as amended] refer to the understanding of the concept of virtual currency contained in the Act on Prevention of Money Laundering and Terrorist Financing [Journal of Laws of 2018, item 723, as amended]. According to the definition included in this Act, virtual currency means the digital representation of exchangeable values in the course of trade on legal means of payment, accepted as a medium of exchange, which can be electronically stored or transferred or can be a subject to electronic commerce that is not:

- legal tender issued by the National Bank of Poland, foreign central banks or other public administration authorities,

- an international settlement unit established by an international organization and accepted by individual countries belonging to or co-operating with that organization,

- electronic money within the meaning of the Act of 19 August 2011 on Payment Services,

- a financial instrument within the meaning of the Act of July 29, 2005, on Trading in Financial Instruments,

- a bill of exchange or a check [Journal of Laws of 2018, item 723, as amended, Article 2, paragraph 2 , point 26].

Until $1^{\text {st }}$ January 2019, there was no clear regulation in the Polish legal system regarding the taxation of income derived from cryptocurrencies. Taxpayers, bearing in mind the guidelines included in the interpretations issued by tax authorities, as well as the case law of administrative courts and the doctrine, settled on general terms, treating income from cryptocurrencies as income from the source of revenues from copyright and other rights referred to in Article 18 of the Act on Personal Income Tax [Journal of Laws of 2018, item 1509, as amended]

It should be noted that as of January $1^{\text {st }}, 2019$, the act implementing provisions regulating the taxation of income from trading in virtual currencies entered into force. According to the newly introduced regulation, income generated by taxpayers who sell virtual currencies for a fee is taxed at a $19 \%$ tax rate. In accordance with Article 22d of the Act on Corporate Income Tax [Journal of Laws of 2018, item 1036, as amended] revenue from the disposal of virtual currencies is: the difference achieved in the tax year between the sum of revenues from virtual currency exchange into the payment instrument, commodity, service or property law other than the virtual currency or from settling other liabilities with virtual currency and the costs of obtaining this income. Similar regulation can also be found in Article 30b paragraph 1 and 2 and Article $17 \mathrm{sec} .1 \mathrm{f}$ of the Act on Personal Income Tax. The costs of obtaining revenues from the paid disposal of a virtual currency are documented expenses directly incurred for the 
acquisition of a virtual currency and costs related to the sale of a virtual currency, including documented expenses incurred for entities referred to in Article 2 paragraph 1 point 12 of the Act on Prevention of Money Laundering and Terrorist Financing [Journal of Laws of 2018, item 723 , as amended].

It should also be clarified that a taxpayer who obtains income from the sale of virtual currencies is obliged to demonstrate the income generated in a given tax year from virtual currency trading in an annual tax declaration "PIT-38" or "CIT-8" and to pay the calculated tax amount without asking the authority. What is important, the income from the paid disposal of virtual currencies is not combined with other income (revenues) achieved by the taxpayer.

Until recently, trading in cryptocurrencies, in particular, bitcoin, was considered almost anonymous [www. cyfrowa.rp.pl/technologie/blockchain/11098-kryptowaluty-to-aktywa-przyszlosci-czy-zabawka-spekulantow (access 23.04.2019)]. Currently, however, due to changes in the European Union law and, consequently, also changes in the Polish law, the anonymity of trading in cryptocurrencies is very limited. The first act in the Polish law whose regulations directly affected virtual currencies, including cryptocurrency, was the Act on Prevention of Money Laundering and Terrorism Financing [Journal of Laws of 2018, item 723, as amended]. The act indicated that the so-called obligated institutions have numerous duties related to disclosing entities with whom transactions are made [www.rp.pl/Prawo-karne/304159914-Kryptowaluty-jako-przedmiot-regulacji.html (access 20.04.2019)]. The catalogue of obligated institutions includes entities conducting business activity included in the provision of services in the scope of:

1. exchanges between virtual currencies and means of payment,

2. exchanges between virtual currencies,

3 . brokering services referred to in point 1 . or 2 . or

4. keeping accounts understood as an electronic collection of identification data providing authorized persons with the possibility of using virtual currency units, including transactions to exchange them [www.orka.sejm.gov.pl/Druki8ka.nsf/0/ BF302BA32C809CC6C125822B00508505/\%24File/2233-uzas.docx (access 25.04.2019)].

The purpose of the introduced act was to counteract introducing legal means of payment of illicit sources into the legal circulation [www.biznes.gazetaprawna.pl/ artykuly/1099679, anonimowosc-na-gieldach kryptowalut.html. (access 23.04.2019)].

At this point, it should be noted that most cryptocurrencies are pseudonymous systems. Because they ensure the transparency of transactions, but they do not allow linking a specific person to a specific financial operation. Currently, transactions based, for example, on Bitcoin one of the most popular cryptocurrencies - are not fully anonymous, as there are methods to effectively track a person who trades bitcoins, for example by means of tracking cookies or using heuristic analysis [www. cseweb.ucsd.edu/ smeiklejohn/files/imc13.pdf (access 30.03.2019)]. Nevertheless, in the case of a part of virtual currencies, when an effort is made, a specific entity may be able to trade in a cryptocurrency in such a way that it will be very difficult to link virtual funds to a person. [www.kryptoportal.pl/poradniki/localbitcoins-com-czyli-anonimowa-sprzedaz-kupno-kryptowalut-pominieciem-gield/?fbclid=IwAR0dEiPXHHnigYRYVeBtEkIe3rdm9VfvsJZ3F8SWi8Rmquim-nhcniml-D4, (access 28.03.2019)]. As a result of legal changes, the process of limiting anonymity in the course of virtual currencies is progressing. More and more exchanges of virtual currencies require the verification of the buyer's data. However, this does not change the fact that there are still such exchanges which do not require such verification.

Despite the indicated legal changes aiming at increasing the transparency of trade in cryptocurrencies, there are still many factors that make taxpayers decide not to tax income derived from the paid disposal of virtual currencies. One of the factors conducive to maintain anonymity is the ability to share investment portfolios and the multiplicity of transactions. The above makes it difficult to identify the entity that rotates cryptocurrencies. At this point, it should be noted that the indicated number of transactions is primarily due to the specificity of trading in cryptocurrencies. The lack of central authorities managing cryptocurrencies also favours anonymity. Another factor hindering the identification of entities trading virtual currencies is the possibility of selling cryptocurrencies without having bank accounts. This is possible, for example, with the help of specially designed devices - bitomats. With bitomats, it is possible to exchange bitcoins directly into cash. In practice, on a display of a bitomat appears QR CODE which should be scanned and which sends bitcoins to the given address. Then we receive the transaction number, and at the same time, a bar code is printed allowing for later payment. Next, we need to wait for the 
confirmation from the network and scan the bar code or enter the transaction number manually. The last step is to collect cash and to confirm the transaction. Exchange of a virtual currency directly into cash, excluding a bank account, also allows, for example, LocalBitcoins start-up, whose aim is to facilitate anonymous virtual currency trading by residents of a given region or country in which it operates. The exchange of virtual currency for cash takes place directly to the hands of the persons exchanging it [www.kryptoportal.pl/poradniki/localbitcoins-com-czyli-anonimowa-sprzedaz-kupno-kryptowalut-pominieciem-gield/?fbclid=IwAR0dEiPXHHnigYRYVeBtEkIe3rdm9VfvsJZ3F8SWi8Rmquim-nhcniml-D4, (access 28.03.2019)].

All these factors make it difficult to detect and reach such transactions by competent tax authorities. Hence, some taxpayers, in the hope of avoiding the need to pay tax, do not show income derived from cryptocurrencies in a tax declaration. It is said that it is not the severity of the punishment that deters offenders, but the detection of crimes. It can be similar in the case of trading in kleptocats. As long as there are ways to even partially anonymous trading in cryptocurrencies, taxpayers will take measures to avoid taxation. Both the EU and Polish legislators introduce a number of solutions to reduce the phenomenon of tax avoidance. One of such methods is, for example, setting limits on daily payments made using bitomats, or the need to authorize transactions with a fingerprint. However, given the high level of technological development of cryptocurrencies and the lack of exposure to the problem by many authorities, this may take some time.

Of course, all the aforementioned factors facilitating the taxpayer's concealment of the income obtained from the sale of cryptocurrencies will not be relevant if the taxpayer purchases significantly in excess of their declared income. Then, tax authorities may initiate proceedings regarding income from undisclosed sources of income. However, in a situation when a taxpayer does not make purchases that exceed their declared financial capacities, or if no "benevolent" taxpayer will facilitate the tax authorities' work and reports on a taxpayer's income not covered by disclosed sources or income from undisclosed sources, tax authorities have very difficult tasks.

Incidentally, it should be mentioned that in addition to the abovementioned factors to honestly account for revenues generated by cryptocurrencies there are also such problems which do not encourage taxpayers. In the case of business activity, losses incurred from cryptocurrencies cannot be offset by revenues from other activities. Also, costs incurred in connection with cryptocurrencies will have to be separated from other costs.

In addition, income obtained from cryptocurrencies will be included in the so-called tribute to solidarity, i.e. if the income from the sale of cryptocurrencies exceeds PLN 1 million, then a taxpayer will have to pay an additional $4 \%$ on the obtained income.

\section{Conclusion}

Due to the fact that until $1^{\text {st }}$ January 2019 there had not been regulations governing the taxation of income from virtual currencies, taxpayers had many doubts as to the correct taxation of such income. Trading in virtual currencies is still largely anonymous, as tax authorities have basically no tools to detect it. What is more, taxpayers are by nature not willing to pay taxes. The above circumstances result in the fact that taxpayers undertake activities aimed at avoiding the taxation of income obtained on this account, which in turn leads to the depletion of tax liabilities. It is also worth noting that the tax office cannot ascertain what the real scale of such an action is. A dishonest taxpayer may avoid fiscal penal liability up to the point where they reveal themselves, for example through reckless shopping, which, given their official income, they cannot afford, or if someone "benevolent" facilitates the matter and reports the improved taxpayer's financial situation, which is not covered by the disclosed sources of income.

\section{Bibliography}

Borucka-Arctowa M. (1980), Świadomość prawna społeczeństwa polskiego, "Ruch prawniczy, ekonomiczny i socjologiczny" z. 1.

Dąbrowska J. (2017), Charakter prawny Bitcoin, "Człowiek w cyberprzestrzeni" no. 1.

Gomułowicz A. (2001), Zasada sprawiedliwości podatkowej, Dom Wydawniczy ABC, Warszawa.

Gomułowicz A. (2010), Zasady podatkowe [in:] L. Etel (red.), System prawa finansowego. Tom III. Prawo daninowe, Wolters Kluwer, Warszawa.

Gomułowicz A., Mączyński D. (2016), Podatki i prawo podatkowe, Wolters Kluwer, Warszawa. 
Już niedługo koniec $\mathrm{z}$ anonimowością na giełdach kryptowalut [online], www.biznes.gazetaprawna.pl/artykuly/1099679,anonimowosc-na-gieldach-kryptowalut. html, access as of 23 April 2019.

Klonowska A. (2017), Luka podatkowa. Skutki dla finansów publicznych, Wydawnictwo C.H. Beck, Warszawa.

Kosikowski C. (2007), Podatki. Problem władzy publicznej i podatników, LexisNexis, Warszawa.

Kozłowska J. (2018), Analiza porównawcza zalet i wad kryptowalut na przykładzie bitcoina, "Rynek-Społeczeństwo-Kultura" no. 1(27).

Kryptowaluty jako przedmiot Regulacji [online], www.rp.pl/ Prawo-karne/304159914-Kryptowaluty-jako-przedmiot-regulacji.html, access as of 20 April 2019.

Kryptowaluty to aktywa przyszłości czy zabawka spekulantów [online], www.cyfrowa.rp.pl/technologie/blockchain/11098-kryptowaluty-to-aktywa-przyszlosci-czy-zabawka-spekulantow, access as of 23 April 2019.

Leoński W. (2013), Zjawisko uchylania się od opodatkowania w grupach społeczno-zawodowych, "Zeszyty Naukowe Wydziału Nauk Ekonomicznych" no. 1.

LocalBitcoins.com, czylianonimowasprzedażikupnokryptowalut z pominięciem giełd [online], www.kryptoportal.pl/ poradniki/localbitcoins-com-czyli-anonimowa-sprzedaz-kupno-kryptowalut-pominieciem-gield/?fbclid=IwAR0dEiPXHHnigYRYVeBtEkIe3rdm9VfvsJZ3F8SWi8Rmquim-nhcniml-D4, access as of 28 March 2019.

Meiklejohn S., Pomarole M., Jordan G., Levchenko K., McCoy D., Voelker G., Savage S., A Fistful of Bitcoins: Characterizing Payments Among Men with No Names [online], www.cseweb.ucsd.edu/ smeiklejohn/files/ imc13.pdf, access as of: 30 of March 2019.

Pasternak-Malicka M. (2013), Mentalność i moralność podatkowa a reakcje gospodarstw domowych na obowiazek podatkowy, "Modern Management Review" no. 1.
Podstawykorzystania z walut cyfrowych [online] www.gov.pl/ documents/31305/436699/Podstawy+walut+cyfrowych. pdf/7a000d7b-2544-f2c7-b532-991a3ee6049a?fbclid=IwAR2zdc7Qv6WeSiNg9vaB7YgPj320Llm2TYDoaIFXO5eXrWmfOhyBiTevXYQ, access as of 28 March 2019.

Schmölders G. (1932), Steuermoral und Steuerbelastung, Carl Heymanns Verlag, Berlin.

Sztopmka P. (2002), Socjologia. Analiza społeczeństwa, Wydawnictwo Znak, Kraków.

The Bible (2011), Gospel of Matthew 12:12-17, Wydawnictwo Świętego Wojciecha, Poznań.

Uzasadnienie do projektu ustawy o przeciwdziałaniu praniu pieniędzy i finansowaniu terroryzmu, VII kadencja, druk sejm. nr 2233 [online], www.orka.sejm.gov.pl/Druki8ka. nsf/0/BF302BA32C809CC6C125822B00508505/\%24File/2233-uzas.docx, access as of 25 April 2019.

Ziembiński Z. (1980), Porzadek rozprawiania o sprawiedliwości, "Państwo i prawo" z. 1.

\section{Legal acts}

The Constitution of the Republic of Poland of 2 April 1997 (Journal of Laws No. 78, item 483 as amended).

Act on Personal Income Tax of 26 July of 1991 (Journal of Laws of 2018, item 1509, as amended).

Act on Corporate Income Tax of 15 February 1992 (Journal of Laws of 2018, item 1036, as amended).

Act on Prevention of Money Laundering and Terrorist Financing of 1 March 2018 (Journal of Laws of 2018, item 723 , as amended).

\section{Authors biographies}

Paulina Grodzka - PhD Student, Faculty of Law, University of Bialystok, and $2^{\text {nd }}$ Year Economy Student, Faculty of Economy and Management, University of Bialystok.

Agnieszka Modzelewska - PhD Student, Faculty of Law, University of Bialystok. 